\title{
Karakteristik Pengawasan terhadap Penyidik Militer dalam Proses Peradilan Pidana Militer
}

\author{
Agus Setiyawan Dwi Arianto \\ tiyanaja10@gmail.com \\ Universitas Airlangga
}

Keywords:
Supervision
Characteristics;
Investigators;
Military Justice.

\begin{abstract}
Military criminal procedural law has characteristics of supervision of investigators that are different from surveillance of existing investigators in the general criminal justice as stipulated in the Criminal Procedure Code, military criminal procedural law does not recognize the external supervision system or pretrial conducted on investigators in carrying out the investigation process regulated in the Criminal Procedure Code, because in the military environment there is a principle of unity of command which is regulated in Law Number 31 of 1997 concerning Military Perdilan. So the supervision of investigators in carrying out the investigation process within the Military Court is only in the form of internal supervision conducted within the TNI organization, and the form of internal supervision is in the form of technical supervision. If the suspect is harmed by the investigator's actions in carrying out an arbitrary military investigation process and does not comply with the investigation procedures in military criminal procedure law, the suspect can still make an effort through internal supervision within the TNI organization itself over the military investigator's actions by reporting to the superiors those who have the right to punish (Ankum) as a form of supervision possessed by Ankum, but also can report the actions of military investigators in the trial process within the Military Court.
\end{abstract}

\begin{abstract}
Kata Kunci:
Abstrak

Karakteristik Pengawasan; Penyidik; Hukum acara pidana militer memiliki karakteristik pengawasan terhadap penyidik yang berbeda dengan pengawasan terhadap penyidik yang ada dalam peradilan pidana umum sebagaimana diatur dalam KUHAP, hukum acara pidana militer Peradilan Militer. tidak mengenal sistem pengawasan eksternal atau praperadilan yang dilakukan pada penyidik dalam menjalankan proses penyidikan yang diatur dalam KUHAP, karena dalam lingkungan militer terdapat asas kesatuan komando yang diatur dalam Undang-Undang Nomor 31 Tahun 1997 tentang Perdilan Militer. Jadi pengawasan terhadap penyidik dalam menjalankan proses penyidikan di lingkungan Peradilan Militer hanya berupa pengawasan internal yang dilakukan dalam organisasi TNI, dan bentuk pengawasan internalnya berupa pengawasan teknis. Jika tersangka dirugikan atas tindakan penyidik dalam menjalankan proses penyidikan militer yang semena-mena dan tidak sesuai prosedur penyidikan dalam hukum acara pidana militer, tersangka tetap dapat melakukan upaya melaui pengawasan internal yang ada dalam organisasi TNI itu sendiri atas tindakan penyidik militer tersebut dengan mengadukannya kepada atasan yang berhak menghukum (Ankum) sebagaimana bentuk pengawasan yang dimiliki Ankum, selain itu juga dapat mengadukan tindakan penyidik militer tersebut di proses persidangan dalam lingkungan Peradilan Militer.
\end{abstract}


Agus Setiyawan: Karakteristik Pengawasan terhadap...

\section{Pendahuluan}

Negara Republik Indonesia memiliki dua sistem peradilan pidana permanen untuk yustisiabel yang berbeda, yaitu peradilan pidana untuk orang sipil dan peradilan militer untuk militer yang masing-masing memiliki yurisdiksi dan yustisiabel yang berbeda. Masing-masing lingkungan peradilan tersebut memiliki kompetensi dan wewenang mengadili yang berdiri sendiri dan terpisah satu sama lain. Masing-masing memiliki kompetensi absolut, sehingga secara mutlak satu lingkungan peradilan tidak boleh dimasuki dan dicampuri oleh lingkungan peradilan yang lain. Lingkungan Peradilan Umum dan Peradilan Militer (juga Peradilan Agama dan Peradilan Tata Usaha Negara) masing-masing berdiri sendiri dengan fungsi dan wewenang mutlak, tidak bisa dicampuri oleh lingkungan peradilan yang lain.

Hukum militer dari suatu negara merupakan bagian yang tak terpisahkan dari sistem hukum yang berlaku di suatu negara termasuk juga di Indonesia. Pada dasarnya hukum militer dapat diberikan pengertian secara singkat dan sederhana, yang menyebutkan bahwa hukum militer mengatur tentang orangorang yang disebut sebagai anggota militer. Anggota militer sendiri tunduk pada peradilan khusus yang disebut dengan peradilan militer, sebagimana dijelaskan dalam Pasal 9 angka 1 Undang-Undang Nomor 31 Tahun 1997 pengadilan dalam lingkungan peradilan militer hanya berwenang mengadili tindak pidana yang dilakukan oleh seseorang yang pada waktu melakukan tindak pidana adalah: prajurit, yang berdasarkan undang-undang dipersamakan dengan prajurit, anggota suatu golongan atau jawatan atau badan atau yang dipersamakan atau dianggap sebagai prajurit berdasarkan undang-undang, dan seseorang yang berdasarkan keputusan Panglima dengan persetujuan Menteri Kehakiman harus diadili oleh suatu Pengadilan dalam lingkungan peradilan militer. ${ }^{1}$

1 Moch Faisal Salam, Hukum Pidana Militer Di Indonesia (Mandar Maju Bandung 2006).[30]. 
Keberadaan peradilan militer sendiri sangat penting karena diperlukan untuk penegakan hukum bagi anggota militer yang melakukan pelanggaranpelanggaran atau bahkan suatu tindak pidana, karena pada hakekatnya anggota militer juga merupakan masyarakat sosial yang tidak luput dari berbagai kesalahan dan kekhilafan yang dilakukannya baik pada saat menjalankan dinas ataupun pada saat di luar dinas kerjanya. Dipandang dari segi hukum, maka anggota militer mempunyai kedudukan yang sama dengan anggota masyarakat biasa, artinya bahwa sebagai warga negara, baginyapun berlaku semua ketentuan hukum yang berlaku, baik hukum pidana, perdata, acara pidana dan acara perdata. Perbedaannya terlihat hanya karena adanya beban kewajiban yang lebih banyak dimandatkan oleh Negara kepada TNI daripada masyarakat biasa dalam hal pertahanan negara. Walaupun pada hakekatnya setiap warga negara wajib ikut serta membela negaranya sebagaimana yang tercantum dalam pasal 30 Undang-Undang Dasar Republik Indonesia 1945, akan tetapi pembelaan atau pertahanan negara ini dilakukan Angkatan Bersenjata sebagai intinya sehingga tugas Pokok Angkatan Bersenjata adalah mempertahankan kedaulatan negara dan kewibawaan pemerintah dengan melakukan pertempuran-pertempuran dengan musuh baik dari dalam maupun luar negeri dalam rangka menegakkan keamanan dalam negeri. ${ }^{2}$

Peradilan Militer mempunyai beberapa kekhususan dalam proses penegakan hukum yang berbeda dengan KUHAP, salah satunya adalah Peradilan Militer tidak mengenal suatu sistem pengawasan yang dinamakan praperadilan sebagai suatu sistem pengawasan eksternal karena di dalam hukum acara pidana militer yang diatur dalam Undang-Undang Republik Indonesia Nomor 31 Tahun 1997 tentang Peradilan Militer terdapat asas kesatuan komando (unity of command), dimana asas kesatuan komando adalah dalam kehidupan militer dengan struktur organisasinya seorang komandan mempunyai kedudukan sentral dan bertanggungjawab penuh terhadap kesatuan dan anak buahnya. Oleh karena itu

2 Moch. Faisal Salam, Peradilan Militer Di Indonesia (Mandar Maju Bandung 2004).[20]. 
Agus Setiyawan: Karakteristik Pengawasan terhadap...

seorang komandan diberi wewenang penyerahan perkara dalam penyelesaian perkara pidana dan kewajiban untuk menyelesaikan sengketa Tata Usaha Angkatan Bersenjata yang diajukan anak buahnya melalui upaya administrasi.

Praperadilan ini di dalam KUHAP memegang peran penting sebagai bagian dari perwujudan perlindungan terhadap Hak Asasi Manusia terhadap tindakan yang tidak mempunyai dasar hukum dan melanggar batasan-batasan yaitu penguasa atau para penegak hukum yang melakukan penyalahgunaan wewenang (Detournement de Pouvoir) dan perbuatan yang sewenang-wenang (Abus de Droit). ${ }^{3}$ Dimana hal ini akan berimplikasi terhadap adanya upaya yang diajukan masyarakat yang menjadi korban atas tindakan sewenang-wenang yang dilakukan penguasa atau para penegak hukum dalam menjalankan prosedur pemeriksaan.

Dengan tidak adanya Praperadian sebagai suatu sistem pengawasan dalam hal ini pengawasan eksternal salah satunya terhadap proses penyidikan yang dilakukan oleh para penyidik, maka dari itu dalam hal tugas dan wewenang pengawasan terhadap penyidik di lingkungan Peradilan Militer dalam menjalankan proses penyidikan dilakukan oleh internal di lingkungan Tentara Nasional Indonesia itu sendiri atau berupa pengawasan internal yang dilakukan oleh Oditur Jenderal, Direktur Pembinaan Penyidikan (DIRBINIDIK), dan Atasan yang Berhak Menghukum (Ankum) sebagaimana yang telah diatur dalam Undang-Undang Nomor 31 Tahun 1997 tentang Peradilan Militer atau diatur dalam peraturan perundang-undangan militer yag lain.

Kebijakan legislatif yang berkaitan dengan lembaga penyidik harus disusun secara jelas agar dapat membentuk satu kesatuan yang integral dengan keseluruhan kebijakan proses penegakan hukum pidana. Dalam berlangsungnya suatu penyidikan, pengawasan merupakan salah satu komponen terpenting yang harus ada demi menjamin pihak yang terlibat telah menjalankan fungsinya sesuai

3 Hardianto Djanggih dan Yusuf Saefudin, 'Pertimbangan Hakim Pada Putusan Praperdilan : Studi Putusan Nomor: 09/PID.PRA/2016/PN.Lwk Tentang Penghentian Penyidikan Tindak Pidana Politik Uang' (2017) 17 Jurnal Penelitian Hukum DE JURE < https:/ / ejournal.balitbangham. go.id/index.php/dejure/article/view/254>.[416]. 
dengan peraturan yang berlaku. Pengawasan dilaksanakan untuk memperoleh informasi apakah penyelenggaraan teknis penyidikan, pengelolaan, administrasi penyidikan, dan pelaksanaan tugas umum penyidikan telah dilaksanakan sesuai dengan rencana dan peraturan perundang-undangan yang berlaku. Hal ini untuk menghindari adanya kesewenang-wenangan dan kekeliruan dalam proses penyidikan. Selain itu pengawasan terhadap penyidik peradilan militer ini nantinya juga berkaitan dengan kepentingan terhadap perlindungan hakhak tersangka pelaku tindak pidana yang dilakukan oleh militer, karena pada dasarnya baik itu orang militer ataupun orang yang bukan militer punya hak yang tidak boleh dilanggar dalam keadaan apapun sebagaimana dijlaskan dalam Pasal 2 Undang-undang Nomor 34 Tahun 2004 tentang Tentara nasional Indonesia yang menyatakan bahwa seorang TNI sangat menjunjung tinggi hukum dan HAM.

\section{Bentuk Pengawasan Internal Terhadap Penyidik Militer}

Pengawasan (toezicht, supervision) menurut Bagir Manan, diartikan sebagai "suatu bentuk hubungan dengan legal entity yang mandiri, bukan hubungan internal dari entitas yang sama. Bentuk dan isi pengawasan dilakukan sematamata menurut atau berdasarkan ketentuan undang-undang". ${ }^{\text {Pengawasan juga }}$ diartikan sebagai alat untuk menilai kesesuaian antara pelaksanaan dengan perencanaan apakah telah sesuai dengan aturan dan mekanisme yang berlaku. ${ }^{5}$ Secara umum, pengawasan adalah salah satu fungsi manajemen kontrol yang selanjutnya disebut pengawasan dalam arti luas. Pengawasan disebut dengan 'controlling' yang juga berati fungsi pengendalian. Pengawasan adalah segala sesuatu atau kegiatan untuk mengetahui dan menilai kenyataan yang sebenarnya tentang pelayanan tugas atau pekerjaan apakah sesuai dengan semestinya atau

4 Derita Prapti Rahayu, ‘Pengawasan Preventif Sebagai Kontrol Pusat Terhadap Daerah Di Era Reformasi' (2015) 2 Jurnal Ilmu Hukum Padjadjaran <http://jurnal.unpad.ac.id/pjih/article/ view/9458>. [450].

5 La Sensu, Muhamad Ikbal Safwan, Guasman Tatawu, 'Analisis Hukum Independensi Inspektorat Daerah Dalam Penyelenggaraan Pengawasan Pemerintahan Daerah', (2019) 1 Halu Olea Legal Research' (2019) 1 Halu Oleo Legal Research <http://ojs.uho.ac.id/index.php/holresch/article/view/6148>.[7]. 
Agus Setiyawan: Karakteristik Pengawasan terhadap...

tidak. "Tujuan Pengawasan adalah supaya proses pelaksanaan dilakukan sesuai dengan ketentuan-ketentuan rencana dan melakukan tindakan perbaikan jika terdapat penyimpangan-penyimpangan (deviasi)" ${ }^{6}$

Pengawasan ini dapat dibedakan atas pengawasan yang bersifat intern dan ekstern. Pengawasan intern diartikan bahwa pengawasan dilakukan oleh suatu badan yang secara organisatoris atau struktural masih termasuk dalam lingkungan pemerintah itu sendiri. Bentuk control semacam ini dapat digolongkan dalam jenis teknis-administratif atau built-in kontrol. Pengawasan ekstern adalah pengawasan bersifat eksternal yaitu kontrol yang dilakukan secara tidak langsung melalui badan-badan peradilan (judicial control) ketika terjadi suatu sengketa atau perkara yang menyangkut pihak pemerintah. Pengawasan terhadap penyidik militer berdasarkan Undang-Undang Nomor 31 Tahun 1997 tentang Peradilan Militer atau peraturan perundang-undangan militer yang lain dilakukan oleh Oditur Jenderal, Dirbinidik (Direktur Pembinaan Penyidikan), dan Ankum (Atasan yang Berhak Menghukum).

Bentuk pengawasan yang dilakukan terhadap penyidik militer dalam melakukan proses penyidikan oleh Oditur Jenderal sebagaimana tugas dan kewenangannya ini hanya berupa pengawasan teknis, dimana pengawasannya hanya akan dilakukan atau berperan ketika ada kendala di lapangan dalam proses penyidikan, disini pengawasan Oditur Jenderal dapat dilihat dalam perannya memberikan saran, dan pentunjuk mengenai penyelesaian permasalahan yang terjadi dalam proses penyidikan di lapangan yang dilakukan oleh penyidik sehingga Oditur Jenderal tidak terlibat secara langsung dalam proses pengawasan penyidikan di lapangan melainkan hanya menjalankan fungsi pengawasan secara teknis saja. ${ }^{7}$ Pengawasan teknis yang dilakukan Oditur Jendral ini mengenai pemberian petunjuk-petunjuk saran mengenai proses permasalahan dalam melaksanakan penyidikan dilakukan pada saat Rakernas (Rapat Kerja Nasional) yang dilaksanakan satu tahun sekali biasanya dengan dihadriri penyidik baik dari

\footnotetext{
6 ibid.

7 Wawancara dengan Oditur Militer Surabaya, Surabaya, Tanggal 3 Oktober 2019.
} 
Oditur Militer, Polisi Militer ataupun Ankum (Atasan Yang Berhak Menghukum). Dalam rapat ini para penyidik menyampaikan kendala-kendala yang pernah terjadi dalam proses penyidikan dan Oditur Jenderalnya memberikan solusi, saran ataupun petunjuk kepada para penyidik tentang penyelesaian kendala-kendala yang pernah terjadi dalam proses penyidikan yang disepakati bersama oleh para penyidik.

Pembinaan dan penggunaan tugas dan kewenangan Polisi Militer sepenuhnya diserahkan kepada staf masing-masing wilayah baik Polisi Militer AL, AD atau AU. Dalam hal pengawasan terhadap penyidik militer dalam lingkungan Polisi Militer dilakukan oleh Direktur Pembinaan Penyidikan (DIRBINIDIK) di masing-masing wilayah, selain itu juga mempunyai fungsi dan tugas yang meliputi segala usaha, pekerjaan, dan keaktifan yang berkenaan dengan pembinaan dan operasional penyidikan perkara pidana serta penyelenggaraan laboratorium kriminalistik. Bentuk pengawasan yang dilakukan Direktur Pembinaan Penyidikan (DIRBINIDIK) terhadap penyidik militer dalam lingkungan Polisi Militer diatur dalam Surat Keputusan Kasad Nomor Kep / 49 / XII / 2006 tanggal 9 Desember 2006 adalah dengan melakukan pembinaan penyidikan seperti, memberikan petunjuk-petunjuk terkait syarat-syarat materil ataupun formil dalam berkas penyidikan yang menurut Oditur Militer terdapat kekurangan, menampung keluhan penyidik dan memberikan saran atau petunjuk yang sesuai dengan petunjuk atau arahan yang telah diberikan oleh Oditur Jenderal selaku pembina teknis penyidikan ketika terjadi kendala dalam proses penyidikan.

Ankum berdasarkan jenjangnya yang diatur dalam Pasal 22 Undang-Undang Nomor 25 Tahun 2014 tentang Hukum Disiplin Prajurit terdiri dari Ankum, Ankum Atasan, Ankum dari Ankum Atasan, dan Ankum Tertinggi. Dalam hal menjalankan tugasnya yang didasarkan pada kewenangan yang telah diberikan, Ankum sendiri harus diawasi dimana pengawasannya sebagaimana dijelaskan dalam Pasal 23 Undang-Undang Nomor 25 Tahun 2014 tentang Hukum Disiplin Prajurit dilakukan oleh :

1. Ankum Atasan adalah Atasan Langsung dari Ankum yang menjatuhkan 
Agus Setiyawan: Karakteristik Pengawasan terhadap...

Hukuman Disiplin Militer (Pasal 1 angka 13) Undang-Undang Nomor 25 Tahun 2014 tentang Hukum Disiplin Prajurit.

2. Ankum dari Ankum Atasan adalah Atasan Langsung dari Ankum Atasan yang menjatuhkan Hukuman Disiplin Militer (Pasal 1 Angka 14) Undang-Undang Nomor 24 Tahun 2014 tentang Hukum Disiplin Prajurit.

3. Ankum Tertinggi adalah Panglima (Pasal 22 ayat 2) Undang-Undang Nomor 25 Tahun 2014 tentang Hukum Disiplin Prajurit.

- Panglima Tentara Nasional Indonesia yang selanjutnya disebut Panglima aalah perwira tinggi Militer yang memimpin Tentara Nasional Indonesia. (Pasal 1 angka 17) Undang-Undang Nomor 25 Tahun 2014.

Fungsi pengawasan Ankum dilakukan terhadap penyidik Oditur Militer dan penyidik Polisi Militer bukan dilakukan terhadap penyidik Ankum yang pengawasannya dilakukan oleh Ankum Atasan, Ankum dari Ankum Atasan, dan Ankum Tertinggi, karena Ankum sendiri tidak pernah melakukan proses penyidikan di lapangan atau turun langsung untuk melakukan penyidikan. Sehingga pengawasan Ankum terhadap penyidik militer hanya dilakukan terhadap penyidik Oditur Militer dan penyidik Polisi Militer, dimana bentuk pengawasannya adalah sama dengan bentuk pengawasan yang ada di dalam Oditur Militer maupun Polisi Militer yang berupa bentuk pengawasan teknis, kewajiban untuk melaporkan proses pelaksanaan penyidikan dan hasil penyidikan kepada Ankum merupakan bentuk pengawasan yang dilakukan oleh Ankum terhadap penyidik militer sebagaimana diatur dalam Pasal 99 dan Pasal 101 ayat (1) Undang-Undang Nomor 31 Tahun 1997 tentang Peradilan Militer.

Bentuk pengawasan terhadap penyidik militer dalam menjalankan proses penyidikan di lingkungan Peradilan Militer yang dilakukan oleh Oditur Jenderal, Dirbinidik (Direktur Pembinaan Penyidikan), dan Ankum sebagaimana yang ada dalam hukum acara pidana militer yang diatur dalam Undang-Undang Nomor 31 Tahun 1997 tentang Peradilan Miiter atau diatur dalam peraturan perundangundangan militer yang lain berbeda dengan bentuk pengawasan terhadap penyidik dalam menjalankan proses penyidikan yang diterapkan dalam Peradilan Pidana Umum. Hal ini dapat dilihat dalam bentuk-bentuk pengawasan terhadap penyidik dalam lingkungan Peradilan Militer sebagimana yang telah dijelaskan diatas adalah bentuk pengawasan teknis, sementara bentuk pengawasan terhadap 
penyidik dalam menjalankan proses penyidikan dalam lingkungan Peradilan Pidana Umum disamping bentuk pengawasannya berupa pengawasan teknis terdapat juga bentuk pengawasan lapangan sebagaimana yang dilakukan oleh WASSIDIK (Pengawas umum) dalam lingkungan Peradilan Pidana Umum. Selain itu dalam Peradilan Pidana Umum juga mengenal atau terdapat bentuk pengawasan eksternal yang dikenal dengan lembaga Praperadilan dimana salah satu fungsinya yaitu untuk mengawasi jalannya proses penyidikan yang dilakukan oleh penyidik dalam lingkungan Peradilan Pidana Umum.

Jadi pengawasan terhadap penyidik militer dalam menjalankan proses penyidikan di lingkungan Peradilan Militer hanya bersifat pengawasan internal yang dilakukan di dalam organisasi Tentara Nasional Indonesia itu sendiri, yang masing-masing pelaksanaan pengawasannya dilakukan oleh Oditur Jenderal, Direktur Pembinaan Penyidikan, dan Ankum sebagaimana yang telah diatur dalam Undang-Undang Nomor 31 Tahun 1997 tentang Peradilan Militer atau Peraturan perundang-undangan militer yang lain.

\section{Upaya Tersangka Terhadap Tindakan Atasan yang Berhak Menghukum}

Upaya menurut kamus besar bahasa Indonesia (KBBI) diartikan sebagai usaha kegiatan yang mengerahkan tenaga, pikiran, untuk mencapai suatu tujuan. Upaya juga berarti usaha, akal, ikhtiar untuk mencapai suatu maksud, memecahkan persoalan mencari jalan keluar. Dalam proses penyidikan ada kemungkinan tersangka mengalami tindakan yang semena-mena dan tidak sesuai prosedur penyidikan sebagaimana diatur dalam peraturan perundang-undangan oleh penyidik. atas hal tersebut tersangka dapat melakukan upaya praperadilan sebagaimana diatur di Pasal 77 KUHAP dalam lingkungan Peradilan Pidana Umum. Sementara upaya yang dapat dilakukan tersangka dalam lingkungan Peradilan Militer yang mengalami tindakan semena-mena dan tidak sesuai prosedur penyidikan dalam proses acara pidana militer tidak bisa melakukan upaya praperadilan seperti yang ada pada Peradilan Pidana Umum. Meski tidak diatur dalam hukum acara pidana militer tersangka tidak hanya diam atas 
tindakan penyidik yang sewenang-wenang dan tidak sesuai prosedur penyidikan sehingga tersangka dirugikan atas hal tersebut.

Kemudian dibandingkan dengan KUHAP, upaya yang dapat dilakukan tersangka dalam lingkungan Peradilan Militer adalah langsung melakukan pengaduan atau melaporkan penyidik militer kepada Atasan Berhak Menghukum (Ankum) yang ada di dalam wilayah komandonya atas tindakan penyidik militer yang sewenang-wenang dan tindakan yang tidak sesuai dalam prosedur penyidikan sebagaimana yang telah diatur dalam hukum acara pidana sehingga tersangka dirugikan atas hal tersebut.

Undang-Undang kemiliteran memberikan kewenangan kepada tiap-tiap Komandan Satuan untuk berkedudukan sebagai Ankum atau Atasan Berhak Menghukum, hal ini dilakukan untuk menegakkan hukum terhadap prajurit yang berada di bawah wewenang komandonya. Berdasarkan Pasal 1 angka 12 UndangUndang Nomor 25 tahun 2014 tentang Hukum Disiplin Militer yang dimaksud Ankum adalah Atasan Yang Berhak Menghukum di lingkungan Angkatan Bersenjata Republik Indonesia yang berhak menjatuhkan hukuman disiplin prajurit yang berada di bawah komandonya, pengertian ini berbeda dengan yang ada dalam Pasal 1 angka 9 Undang-Undang Nomor 31 Tahun 1997 tentang Peradilan Militer yang menyatakan Ankum atau Atasan Berhak Menghukum adalah Atasan langsung yang mempunyai hak untuk menjatuhkan hukuman disiplin terhadap prajurit yang berada dibawah wewenang komandonya dan juga berhak untuk melakukan penyidikan.

Berdasarkan pengertian Ankum sebagaimana yang telah dijelaskan diatas, selanjutnya dalam Undang-Undang Nomor 25 tahun 2014 tentang Hukum Disiplin Prajurit, Ankum berwenang untuk :

Pasal 21

(1) Ankum berwenang penuh berwenang menjatuhkan semua jenis Hukuman Disiplin Militer kepada Militer yang berada di bawah wewenang 
komandonya. ${ }^{8}$

(2) Ankum terbatas berwenang untuk menjatuhkan semua jenis Hukuman Disiplin Militer kepada Militer yang berada di bawah wewenang komandonya, kecuali penahanan disiplin berat terhadap perwira. ${ }^{9}$

(3) Ankum sangat terbatas berwenang untuk menjatuhkan Hukuman Disiplin Militer teguran dan penahanan ringan kepada bintara dan tamtama yang berada di bawah wewenang komandonya. ${ }^{10}$

Pasal 23

(1) Ankum berwenang untuk melakukan atau memerintahkan untuk melakukan pemeriksaan terhadap Militer yang berada di bawah wewenang komandonya, menjatuhkan Hukuman Disiplin Militer terhadap Militer yang berada di bawahh wewenang komandonya, dan menunda pelaksanaan Hukuman Disiplin Militer yang telah dijatuhkan.

(2) Ankum Atasan berwenang untuk menunda pelaksanaan Hukuman Disiplin Militer, memeriksa serta memutus pengajuan keberatan, dan mengawasi serta mengendalikan Ankum yang berada dibawahnya.

(3) Ankum dari Ankum Atasan berwenang untuk menunda pelaksanaan Hukuman Disiplin Militer, memeriksa serta memutus pengajuan keberatan tingkat akhir, dan mengawasi dan mengendalikan Ankum yang berada dibawahnya.

(4) Ankum tertinggi berwenang untuk menunda pelaksanaan Hukuman Disiplin Militer, memeriksa serta memutus pengajuan keberatan tingkat akhir dan bersifat final, dan mengawasi serta mengendalikan Ankum yang berada dibawahnya.

Selain itu kewenangan Ankum juga diatur dalam Undang-Undang Nomor

31 Tahun 1997 tentang Peradilan Militer, seperti :

Pasal 74

a. Melakukan penyidikan terhadap Prajurit bawahan yang berada di bawah wewenang komandonya yang pelaksanaanya dilakukan oleh Penyidik Polisi Militer dan Oditur Militer.

b. Menerima laporan pelaksanaan penyidikan dari Penyidik Polisi Militer dan Oditur Militer.

c. Menerima berkas perkara hasil penyidikan dari Penyidik Polisi Militer dan Oditur Militer.

d. Melakukan penahanan terhadap Tersangka anggota bawahannya yang ada di bawah wewenang komandonya.

8 Dini Dewi Heniarti, Sistem Peradilan Militer Di Indonesia Tinjauan Teoritis, Praktis, Perbandingan Hukum Dan Pembaharuan Hukum Nasional (PT Refika Aditama Bandung 2017).[83].

9 ibid.

10 ibid. 
Agus Setiyawan: Karakteristik Pengawasan terhadap...

Dasar tersangka dapat melaporkan atau mengadukan penyidik militer yang melakukan tindakan sewenang terhadap tersangka atau menimbulkan kerugian terhadap tersangka dalam proses penyidikan ke Ankum adalah karena sebagaimana wewenang Ankum dalam Pasal 99 ayat (2) dan (3) Undang-Undang Nomor 31 Tahun 1997 tentang Peradilan Militer, yang menyatakan :

Pasal 99

(2) Dalam hal yang menerima laporan atau pengaduan adalah Atasan yang Berhak Menghukum, ia segera menyerahkan pelaksanaan penyidikan kepada Penyidik sebagaimana dimaksud dalam Pasal 69 ayat (1) huruf b (Polisi Militer) atau huruf c (Oditur) untuk melakukan penyidikan.

(3) Dalam hal yang mengetahui, menerima laporan atau pengaduan sebagaimana dimaksud ayat (1) adaalah Penyidik sebagaimana dimaksud dalam Pasal 69 ayat (1) huruf b (Polisi Militer) atau huruf c (Oditur), mereka wajib melakukan penyidikan dan segera melaporkannya kepada Atasan yang Berhak Menghukum Tersangka.

Sebagaimana diatur dalam Pasal 99 ayat (2) dan (3) bahwa setiap penyidik dalam lingkungan Peradilan Militer yang akan melakukan proses penyidikan harus ada izin dari Atasan yang Berhak Menghukum (Ankum). Selain itu Ankum juga mempunyai fungsi komando seperti mengarahkan, mengkordinir, mengendalikan, dan menghukum, sehingga dengan fungsi yang dimiliki Ankum ini Tersangka yang dirugikan atas tindakan penyidik militer yang sewenangwenang dalam proses penyidikan sepatutnya untuk dapat langsung melaporkan tindakan penyidik tersebut langsung kepada Atasan yang Berhak Menghukum (Ankum) agar penyidik yang melakukan tindakan sewenang-wenang tadi langsung ditindak oleh Atasan yang Berhak Menghukum (Ankum).

\section{Upaya Tersangka di Persidangan dalam Lingkungan Peradilan Militer}

Ada beberapa persiapan sebelum persidangan dibuka, antara lain. Pertama, Koatmil atau Koatmilti berdasarkan penetapan sidang mengeluarkan surat panggilan kepada tersangka atau terdakwa dan para saksi dengan mencantumkan waktu dan tempat sidang, pemanggilan tersebut disampaikan kepada Atasan yang Berhak Menghukum (Ankum) dengan tembusan kepada Perwira Penyerah Perkara (Papera). Kedua, Koatmil atau Koatmilti membuat surat perintah kepada masing- 
masing Oditur selaku penuntut umum. Ketiga apabila Oditur selaku penuntut umum ingin mengubah surat dakwaan dengan maksud untuk disempurnakan, maka perubahan tersebut diserahkan ke pengadilan dalam lingkungan Peradilan Militer selambat-lambatnya 7 hari sebelum sidang dimulai dan perubahan surat dakwaan dilakukan hanya satu kali selanjutnya perubahan tersebut disampaikan kepada tersangka atau terdakwa dan Perwira Penyerah Perkara (Papera), mengenai penahanan dalam hal perkara sudah dilimpahkan kepada pengadilan dalam lingkungan Peradilan Militer maka kewenangan penahanan beralih kepada pengadilan dalam lingkungan Peradilan Militer.

Setelah semua kelengkapan sidang telah lengkap maka sidang dapat segera dimulai, dimana tahapan pelaksanaan persidangan dimulai dengan. Pertama, hakim ketua memerintahkan kepada Oditur untuk memanggil terdakwa dan Oditur memerintahkan petugas untuk menghadirkan terdakwa ke ruang sidang. Kedua, hakim ketua memerintahkan Oditur supaya membacakan surat dakwaan dengan berdiri dan memerintahkan terdakwa supaya berdiri dalam keadaan sempurna. Ketiga, dalam hal terdakwa atau penasehat hukumnya mengajukan keberatan (eksepsi) bahwa pengadilan tidak berwenang mengadili perkaranya atau dakwaan tidak dapat diterima atau surat dakwaan harus dibatalkan, sesudah diberi kesempatan kepada Oditur untuk menyatakan pendapatnya selanjutnya majelis hakim mengadakan musyawarah untuk mempertimbangkan keberatan tersebut untuk selanjutnya mengmbil keputusan. Keempat, pemeriksaan saksi dimana Oditur menghadapkan saksi kedepan majelis hakim atas perintah dari hakim ketua lalu Oditur memerintahkan kepada petugas untuk menghadapkan saksi ke persidangan seorang demi seorang menurut pertimbangan hakim, kemudian Oditur, Terdakwa atau Penasehat Hukum dengan perantara Hakim Ketua diberi kesempatan untuk megajukan pertanyaan kepada saksi, dalam memberikan keterangan saksi tidak boleh diganggu, setelah saksi selesai memberikan keterangan hakim ketua memberikan kesempatan kepada terdakwa untukmenanyakan pendapat terdakwa mengenai keterangan saksi tersebut, setelah terdakwa memberikan tanggapannya hakim ketua dapat menanyakan kembali 
Agus Setiyawan: Karakteristik Pengawasan terhadap...

kepada saksi atas tanggapan dari terdakwa tersebut, terdakwa atau penasehat hukumnya melalui hakim ketua dapat diberikan kesempatan untuk mengajukan pertanyaan kepada saksi. Kelima, keterangan terdakwa dimana pemeriksaan ini dimulai setelah pemeriksaan saksi telah didengar keterangannya semua. Keenam, pemeriksaan barang bukti yang dilakukan setelah pemeriksaan saksi dan terdakwa telah selesai semua, hakim ketua memperlihatkan kepada terdakwa semua barang bukti dan menanyakan kepada terdakwa apakah terdakwa mengenal benda tersebut dan menanyakan sangkut pautnya benda itu dengan perkaranya untuk kejelasan tentang peristiwanya. Namun bila dipandang perlu, barang bukti tersebut dapat dilihatkan sebelum pemeriksaan semua saksi dan terdakwa selesai. Ketujuh, sesudah pemeriksaan dinyatakan selesai Oditur mengajukan tuntutan pidana yang selanjutnya terhadap tuntutan, terdakwa atau penasehat hukum mengajukan pembelaannya yang dapat dijawab oleh Oditur dengan ketentuan bahwa terdakwa atau penasehat hukum selalu mendapat giliran terakhir, dan apabila tuntutan, pembelaan, jawaban atas pembelaan sudah selesai hakim ketua menyatakan bahwa pemeriksaan dinyatakan ditutup. Kedelapan, musyawarah majelis hakim, dilakukan setelah semua pemeriksaan semua selesai maka hakim ketua akan menyatakan pemerisaan ditutup. Kemudian menunda sidang untuk memberikan kesempatan kepada majelis hakim untuk bermusyawarah guna untuk mengambil keputusan atas perkara tersebut. Kesembilan, putusan pengadilan, apabila majelis hakim berpendapat bahwa terdakwa terbukti bersalah melakukan tindak pidana yang didakwakan kepadanya maka pengadilan akan menjatuhkan hukuman pidana dalam putusannya. Sementara apabila terdakwa tidak terbukti bersalah sebagaimana dengan apa yang telah didakwakan kepadanya maka pengadilan akan memutus bebas dari segala dakwaan yang telah dipersangkakan kepadanya.

Upaya lain yang dapat dilakukan oleh tersangka jika mendapat tindakan sewenang-wenang yang dilakukan penyidik militer dalam proses penyidika, sehingga tersangka disini dirugikan atas hal tersebut adalah dengan melaporkan atau mengajukan pengaduan atas tindakan tidak mengenakan tersebut pada saat proses pemeriksaan terdakwa di persidangan dalam lingkungan Peradilan 
Militer. Hal ini dapat dilihat dalam Pasal 156 Undang-Undang Nomor 31 Tahun 1997 tentang Peradilan Militer yang menyatakan bahwa apabila keterangan saksi di proses persidangan berbeda keterangannya yang terdapat dalam berita acara pemeriksaan, hakim ketua mengingatkan saksi tentang hal itu serta meminta keterangan mengenai perbedaan yang ada dan dicatat dalam berita acara pemeriksaan sidang. Dalam hal ini tidak hanya bisa terjadi pada saksi namun juga bisa terjadi pada tersangka atau dalam proses persidangan disebut sebagai terdakwa pada waktu pemeriksaan terdakwa. Atas hal tersebut bahwa ada kemungkinan pengakuan tersangka dalam tingkat penyidikan, kemudian dalam pemeriksaan pengadilan pengakuan tersebut dicabut kembali. ${ }^{11}$ Ada beberapa hal yag melatar belakangi kenapa seseorang terdakwa tersebut mencabut pernyataannya, misalnya:

1. Adanya unsur paksaan atau ancaman dari pihak penyidik ketika melakukan pemeriksaan.

2. Adanya perlakuan yang semena-mena pada waktu penyidikan sehingga dalam memberikan pernyataan tersangka, terdakwa ataupun saksi tidak leluasa atau merasa tertekan.

3. Dalam hal proses penyedikan atau pemeriksaan lainnya tidak didasarkan pada peraturan perundang-undangan yang ada sehingga menimbulkan kerugian bagi tersangka, terdakwa ataupun saksi.

Yang jelas dengan adanya hal-hal diatas akan mengakibatkan proses penyidikan yang bertujuan untuk mencari keterangan tindak pidana yang telah dilakukan menjadi bias atau kurang jelas, hal ini sangat melanggar aturan yang berlaku karena sekalipun dalam proses pemeriksaan sebelum masuk ke proses persidangan hak hak yang ada dalam diri tersangka, terdakawa ataupun saksi harus tetap dilindungi.

Untuk mengatasi hal tersebut tidak kemudian pemeriksaan berhenti disitu, untuk membutikan benar atau tidaknya pengaduan terdakwa tersebut

11 Mohammad Taufik Makarao dan Suhasril, Hukum Acara Pidana Dalam Teori Dan Praktek (Ghalia Indonesia Bogor 2010).[131]. 
Agus Setiyawan: Karakteristik Pengawasan terhadap...

yang menimbulkan pernyataan berbeda dalam Berita Acara Pemeriksaan dan pada saat pemeriksaan di dalam persidangan, setelah proses pemeriksaan terhadap keterangan terdakwa dilanjutkan pada pemeriksaan tambahan dengan menghadirkan saksi verbalisan. Verbalisan yaitu dari kata verbal yang artinya secara lisan, bersifat khayalan. Sedangkan Verbalisan Orang (penyidik) yang melakukan proses verbal (penyidikan). Sedangkan saksi verbalisan menurut Hukum Acara Pidana Militer yaitu saksi dari pihak penyidik yang dihadirkan oleh Oditur selaku Jaksa Penuntut Umum (JPU) atau majelis hakim militer, yang mana saksi tersebut bersangkutan dengan perkara yang sedang diperiksa dalam proses persidangan dalam lingkungan Peradilan Militer. Saksi verbalisan ini muncul dikarenakan adanya pernyataan terdakwa untuk mencabut keterangannya atau Berita Acara Pemeriksaan (BAP) karena terdakwa ketika diperiksa pada tingkat penyidikan mengaku ditekan, dipaksa, atau diancam atau hal lain yang sudah disebutkan diatas. ${ }^{12}$ Secara fundamental kata verbalisan adalah istilah yang lazim tumbuh dan berkembang dalam praktek serta tidak diatur oleh Undang-Undang Nomor 31 Tahun 1997 tentang Peradilan Militer atau peraturan lain yang terkait dengan kemiliteran. Menurut makna lesikon dan doktrina, verbalisan adalah nama yang diberikan kepada petugas (politisi atau yang diberikan kepada petugas khusus) untuk menyusun, membuat, atau mengarang berita acara. Kemudian menurut Yan Pramadya Puspa bahwa verbalisan adalah petugas (polisi atau seorang yang diberi tugas khusus) untuk menyusun, atau mengarang proses verbal. Dengan demikian, apabila ditilik dari visi praktik peradilan, eksistensi saksi verbalisan tampak jika dalam persidangan terdakwa menyangkal kebenaran keterangan saksi dan kemudian keterangan dari saksi/terdakwa disidang pengadilan berbeda dengan keterangannya dalam berita acara yang dibuat oleh penyidik.

Keberadaan saksi verbalisan dalam proses pemeriksaan di pengadilan dalam lingkungan Peradilan Militer tidak mutlak harus ada, tergantung bagaimana

${ }^{12}$ Wawancara dengan Oditur Militer Tinggi Surabaya, Surabaya, Tanggal 12 November 2019. 
proses pemeriksaan di pengadilan dalam lingkungan Peradilan Militer itu berjalan. Jika dikehendaki atau apabila ada terdakwa mencabut apa yang ia nyatakan dalam BAP, maka baik Oditur selaku Jaksa Penuntut Umum atau atas inisiatif dari Hakim Militer dapat mengajukan saksi verbalisan. Dalam pemeriksaan di pengadilan, pernyataan saksi penyidik yang dinyatakan di bawah sumpah dapat dikatakan juga sebagai suatu keterangan yang sah. Dalam proses pemeriksaan terhadap saksi verbalisan di persidangan, hakim bebas menilai kebenarannya dan dalam keputusannya dapat menerima atau menyingkirkannya sebagai alat bukti artinya hakim disini tidak terikat pada nilai kekuatan yang terdapat pada saksi verbalisan ini. Untuk menilai sejauh mana kekuatan pembuktian keterangan saksi verbalisan sebagai alat bukti di persidangan tidak lepas dari alat bukti lain, dimana hakim akan mengkaji terlebih dahulu alat bukti yang telah diperiksa baru kemudian mengkaji mengenai keterangan saksi verbalisan tersebut, karena keterangan dari saksi verbalisan ini tidak bisa berdiri sendiri atau diartkan bahwa keterangan saksi verbalisan untuk dapat dijadikan alat bukti maka harus didukung oleh alat bukti lainnya yang di periksa dalam proses persidangan dan juga harus memenuhi batas minimum alat bukti sebagaimana dijelaskan dalam Pasal 171 Undang-Undang Nomor 31 Tahun 1997 tentang Peradilan Militer, yang menyatakan bahwa hakim tidak boleh menjatuhkan pidana kepada seseorang kecuali apabila dengan sekurang-kurangnya atau minimal dengan 2 (dua) alat bukti yang sah ia memperoleh keyakinan bahwa suatu tindak pidana benar-benar terjadi dan terdakwalah yang bersalah melakukannya.

Diluar hasil dari putusan hakim tentang mempertimbangkan dengan menerima atau menolak keterangan dari saksi verbalisan, sekiranya terdakwa tetap berdalih jika pada saat proses penyidikan terdakwa ditekan, disiksa, ataupun proses tersebut tidak sesuai dengan prosedur yang telah diatur dalam peraturan perundang-undangan, terdakwa dapat melaporkan penyidik militer yang melakukan hal-hal tersebut ke pengadilan dalam lingkungan Peradilan Militer dengan dakwaan penganiayaan, pemalsuan ataupun yang lainnya. Atas dasar ini si penyidik militer statusnya berubah menjadi tersangka dan diperiksa 
Agus Setiyawan: Karakteristik Pengawasan terhadap...

di pengadilan dalam lingkungan Peradilan Militer pada proses pemeriksaan yang berbeda. ${ }^{13}$

\section{Kesimpulan}

Pertama adalah bentuk pengawasan internal terhadap penyidik dalam lingkungan Peradilan Militer yang ada dalam hukum acara pidana militer sebagaimana diatur dalam Undang-Undang Nomor 31 Tahun 1997 tentang Peradilan Militer dan peraturan perundang-undangan militer lainnya adalah bentuk pengawasan teknis yang dilakukan Oditur Jenderal, Direktur Pembinaan Penyidikan, dan Ankum, seperti : pemberian saran, petunjuk, solusi mengenai permasalahan yang dihadapi oleh penyidik militer dalam melaksanakan proses penyidikan di lapangan, memberikan petunjuk terkait syarat materil atau syarat formil dalam berkas penyidikan yang menurut Oditur Militer terdapat kekurangan, dan juga kewajiban melaporkan pelaksanaan proses penyidikan dan hasil penyidikan dalam proses penyidikan yang dilakukan oleh penyidik militer.

Kedua adalah dalam hukum acara pidana militer. Tersangka yang dirugikan atas tindakan penyidik militer yang semena-mena dan tidak sesuai dengan prosedur penyidikan sebagaimana telah diatur dalam hukum acara pidana militer, tersangka tetap dapat melakukan upaya atas tindakan yang dilakukan penyidik militer tersebut melalui pengawasan internal yang ada dalam lingkungan organisasi Tentara Nasional Indonesia itu sendiri yaitu dengan mengadukannya kepada Atasan yang Berhak Menghukum (Ankum) secara langsung sebagaimana bentuk pengawasan yang dimiliki Ankum terhadap penyidik militer yaitu bertanggungjawab penuh atas proses pelaksanaan penyidikan dan berakhirnya proses penyidikan. Selain itu juga dapat mengadukan hal itu pada tahap proses persidangan di lingkungan Peradilan Militer.

${ }^{13}$ Wawancara dengan Oditur Militer Tinggi Surabaya, Surabaya, Tanggal 12 November 2019. 


\section{Daftar Bacaan}

\section{Buku}

Dini Dewi Heniarti, Sistem Peradilan Militer Di Indonesia Tinjauan Teoritis, Praktis, Perbandingan Hukum Dan Pembaharuan Hukum Nasional (PT Refika Aditama Bandung 2017).

Moch. Faisal Salam, Peradilan Militer Di Indonesia (Mandar Maju Bandung 2004).

Salam MF, Hukum Pidana Militer Di Indonesia (Mandar Maju Bandung 2006).

Suhasril MTM dan, Hukum Acara Pidana Dalam Teori Dan Praktek (Ghalia Indonesia Bogor 2010).

\section{Jurnal}

Derita Prapti Rahayu, 'Pengawasan Preventif Sebagai Kontrol Pusat Terhadap Daerah Di Era Reformasi' (2015) 2 Jurnal Ilmu Hukum Padjadjaran <http:/ / jurnal.unpad.ac.id/pjih/article/view/9458>.

Muhamad Ikbal Safwan, Guasman Tatawu dan LS, 'Analisis Hukum Independensi Inspektorat Daerah Dalam Penyelenggaraan Pengawasan Pemerintahan Daerah', (2019) 1 Halu Olea Legal Research' (2019) 1 Halu Oleo Legal Research <http://ojs.uho.ac.id/index.php/holresch/article/view/6148>.

Hardianto Djanggih dan Yusuf Saefudin, 'Pertimbangan Hakim Pada Putusan Praperdilan : Studi Putusan Nomor: 09/PID.PRA/2016/PN.Lwk Tentang Penghentian Penyidikan Tindak Pidana Politik Uang' (2017) 17 Jurnal Penelitian Hukum DE JURE <https://ejournal.balitbangham.go.id/index. $\mathrm{php} /$ dejure/article/view/254>.

\section{Wawancara}

Agung Catur Utomo. 2019. “Bentuk Pengawasan Internal terhadap Penyidik Militer". Hasil Wawancara Pribadi: 3 Oktober 2019 , Oditurat Militer Surabaya.

Sri Mulyani. 2019. “Upaya Tersangka jika Dirugikan Penyidik Militer, Hasil Wawancara Pribadi: 12 November 2019 Oditurat Militer Tinggi Surabaya.

How to cite: Agus Setiyawan Dwi Arianto, 'Karakteristik Pengawasan terhadap Penyidik Militer dalam Proses Peradilan Pidana Militer' (2020) Vol. 3 No. 3 Media Iuris. 
--Halaman ini sengaja dibiarkan kosong-- 